\title{
The Influence of BIM Education Improvement on Raising BIM Awareness in Croatia and Slovakia
}

\author{
Sonja Kolarić1*, Tomáš Mandičák², Mladen Vukomanović1, Peter Mesároš² \\ ${ }^{1}$ Department of Construction Management and Economics, Faculty of Civil Engineering, University of Zagreb, \\ Fra Andrije Kačića Miošića 26, 10000 Zagreb, Croatia \\ 2 Department of Construction Technology and Management, Faculty of Civil Engineering, Technical University of Košice, \\ Vysokoškolská 4, 04200 Košice, Slovakia \\ *Corresponding author, e-mail: skolaric@grad.hr
}

Received: 11 February 2019, Accepted: 12 February 2019, Published online: 02 April 2019

\begin{abstract}
Building Information Modeling (BIM) is an intelligent 3D model-based process that enhances productivity and management performance of construction projects. Recognizing many benefits of BIM, governments of the most developed members of the European Union encourage BIM usage which results in a higher BIM awareness and BIM adoption. These facts suggest that BIM is becoming the norm within construction industry. On the contrary, Croatia and Slovakia have been very low in BIM application and have done little to support BIM initiatives. Previous studies suggested several strategies to increase the BIM application, where providing BIM education at university level is one of them, so universities need to update their curricula accordingly. In this study we compared implemented Construction Management (CM) BIM education on master's study at the Faculty of Civil Engineering Košice and Zagreb. The results show that BIM education at the both faculties should be connected with other departments on the same faculty, other disciplines but also with real companies and projects. Such extension will provide civil engineers with wider BIM knowledge related to interoperability, integration, communication, collaboration, standardization and clash detection. Thus, BIM education improvement will have good impact on rising BIM awareness and will be good incentive for further BIM implementation in Croatia and Slovakia. This study is an extension of paper presented on Creative Construction Conference 2018 in Ljubljana. In this paper we showed deeper statistical analysis of CM educational programs in Croatia and Slovakia as well as relationship between BIM awareness and BIM education in both countries.
\end{abstract}

Keywords

BIM awareness, BIM education, Croatia, Slovakia

\section{Introduction}

Building Information Modeling (BIM) is an intelligent 3D model-based process that enhances productivity and management performance of construction projects. Implementation of BIM is steadily gaining popularity in construction industry while practitioners have been quite aware of BIM, but BIM adoption still varies between countries (Denmark 78 \%; Canada 67 \%; UK 48 \%; Japan 46 \%; Czech Republic $25 \%$ ) (Malleson et al., 2016). Moreover, the usage of BIM is increasing and within five years it is expected that BIM usage in design professions in most world countries will be over $80 \%$. These facts suggest that BIM is becoming the norm within construction industry (Malleson et al., 2016). On the contrary, previous studies showed that Croatia and Slovakia have been very low in BIM application where only $0-25 \%$ of construction companies have been used BIM in their business (Kolarić et al., 2016; Mesaroš et al, 2016; Mesaroš and Mandičak, 2017). In some way this is a result of local state authorities' disengagement in supporting BIM implementation. Authors suggested several strategies to increase the BIM application, where providing BIM education at university level is one of them (Salleh and Phui Fung, 2014).

Growing popularity of the BIM has resulted in development of the new professions. By observing BIM trends and practices in the construction industry Uhm et al. identified eight BIM job types which included BIM project manager, director, BIM manager, BIM coordinator, BIM designer, senior architect, BIM MEP coordinator and BIM technician but authors also identified BIM competencies for each BIM job group (Uhm et al., 2017). Moreover, BIM 
professions BIM manager/engineer and BIM project manager are the most common professions connected with the BIM (Wang and Leite, 2014). According to Wang and Leite the BIM manager/engineer is required to understand what BIM is and how it changes the work process, have abilities to create the BIM models, to perform data analysis with existing BIM models, to use BIM visualization and communication tools but also have experience in working with specific BIM tools. In comparison with the BIM manager, BIM project manager may or may not directly use BIM, but has to understand what the BIM is and how it changes the work processes, should have abilities to use BIM as a visualization and communication tool but also to perform data analysis whit existing BIM models (Wang and Leite, 2014). Further, by the EU Directive 2014/24/EU, set forth by European parliament and Council, BIM was clearly indicated as the future of construction industry in EU so many countries in EU have started to mandate the BIM usage on all public projects (BIM Directive, 2018). Thus, BIM knowledge represents important learning outcome in higher students' education, especially in Construction Management (CM) field.

Even though BIM shows promising results and is the current trend in the construction industry, and many countries are obliged to use it, education of construction engineers (pedagogy, curricula, learning outcomes etc.) still has not caught up with the trends (Wang and Leite, 2014). Reasons for absence of BIM in the curricula of civil engineering practices can be found in inadequate and not educated staff, inadequate resources and support to make the curriculum changes and the fact that there is no space left within curriculum (Becerik-Gerber et al., 2011; Abbas et al., 2016; Puolitaival and Perry, 2016; Suwal and Singh, 2018; Puolitaival et al., 2017; Shelbourn et al., 2017). Furthermore, problem connected with the BIM education within CM field is to define learning outcomes, curriculum of courses and specific knowledge which is necessary for future construction and project managers. Besides, researchers (Abbas et al., 2016; Puolitaival and Perry, 2016; Puolitaival et al., 2017) recommended to create a plan for BIM integration into Architects, Engineering and Construction (AEC) curricula and to define the basic BIM knowledge areas important for future civil engineers. These actions will help in creating awareness for the BIM implementation in higher education (Puolitaival and Perry, 2016; Suwal and Singh, 2018; Yusuf et al., 2016). In majority higher educational programs integration and collaboration between disciplines have not been achieved yet. Therefore, the BIM education is often part of separated departments and disciplines with minimal trust between project participants (Puolitaival and Perry, 2016; Macdonald, 2012) and in such environment is hardly to expect encouraging information integrity and collaboration. In response to these problems there are big number of research and studies made on the BIM implementation in education. Thus, authors defined objectives of the BIM CM education which are to evolve student's ability and knowledge to: develop cost estimates and time plans; function in multidisciplinary teams; compare and coordinate the architectural, structural and services models; understand collaboration and interoperability (Boon and Prigg, 2011; Glick et al., 2010; Kim, 2012; Ku and Taiebat, 2011; Lee and Hollar, 2013). Moreover, Sacks and Pikas classified BIM competency topics which are necessary to realize through the first or master's degree level of CM program in three categories: BIM-related general knowledge area and processes (12 topics), BIM technology (10 topics) and BIM applications/functionalities (17 topics) (Sacks and Pikas, 2013; Pikas et al., 2013).

According to previous studies (Kolarić et al., 2017; Kolarić et al., 2018) BIM education in the CM field at Technical University of Košice, Faculty of Civil Engineering has not yet fully extended to the master's level. There have been some courses with BIM education, but not in the CM field whereby BIM knowledge has been more theoretical than a practical one. Likewise, the academic experience which has been reached through BIM education at University of Zagreb, Faculty of Civil Engineering has been a single course collaboration because BIM has been introduced only through one discipline within university (Kolarić et al., 2015; Kolarić et al., 2017). From the above is evident that specific data about learning outcomes and necessary knowledge areas connected with BIM education in CM field currently does not exist. Additionally, deeper analyses of implemented BIM education and BIM courses is necessary to define the way of their extension (Barison and Santos, 2010). So, the aim of this paper is to compare and discuss educational approaches in the CM BIM education of civil engineers at the Faculty of Civil Engineering Košice and Zagreb to define guidelines for the further development of the BIM education on mentioned faculties. Moreover, paper investigates the connection between BIM awareness and BIM education in Croatia and Slovakia (markets with equally widespread BIM application) for further raise of the BIM awareness. This study is an extension of paper presented on Creative Construction Conference 
2018 in Ljubljana. Thus, this paper showed deeper statistical analysis of the CM educational programs in Croatia and Slovakia as well as relationship between BIM awareness and BIM education in both countries.

First, this paper presents methodology of the research conducted at the Faculty of Civil Engineering Košice and Zagreb and then it gives the results and discussion. Finally, the paper gives conclusion and proposes BIM education improvement on both faculties which will have positive impact on raising BIM awareness on both markets.

\section{Methodology}

In this study we surveyed the students after they finished their BIM education on master's study in CM field. They were asked whether they have acquired the required skills in working with BIM tools but also the basic knowledge about the BIM concept. Moreover, we used students' perception of current BIM training to asses and analyze current educational practices in CM area in Croatia and Slovakia. All the students who participated in survey (86 students) have been on the first or second year of CM study program. $34.89 \%$ (53.3\% on first year; $46.7 \%$ on second year) of them study at the Faculty of Civil Engineering Košice while $65.11 \%$ (57.1 \% on first year; $42.9 \%$ on second year) of participants study at the Faculty of Civil Engineering Zagreb.

Part of the survey analyzed in this article consisted of 3 types of questions. The first two types were closed type of questions (yes/no and closed select options). In third analyzed type of questions we gave students list of BIM competencies connected with BIM processes, BIM technology and BIM applications and they should rate their level of knowledge (theoretical, practical or both) acquired thought their BIM education. One of the option was that listed BIM competency was not included in their BIM education. When doing list of BIM competencies we used identified specific BIM competency topics by Sacks and Pikas which are necessary to realize through the first or master degree level of CM study (Sacks and Pikas, 2013). We added 'Cost management' as additional BIM competency in categories BIM processes and BIM technology.

The comparative analysis of the two university groups (Košice and Zagreb) was based on the Mann-Whitney-U test. Accordingly, if p-value is less than alpha than there is a significant difference between tested groups while if p-value is higher than alpha, then there is not a significant difference between groups. Moreover, Friedman test was used to compare the level of students' BIM knowledge (theoretical, practical or both) connected with BIM processes, BIM technology and BIM applications acquired thought the BIM education on each university separately. When doing Friedman test we analyzed only the answers of students who have thought that specific BIM competency topic was included in BIM education at their faculty. Thus, if p-value is less than alpha than there is a significant difference between level of acquired BIM knowledge at the one observed faculty while if $\mathrm{p}$-value is higher than alpha, then there is not a significant difference between acquired level of knowledge. In both tests significance level is 0.05 (alpha $=0.05$ ).

\section{Results}

After BIM education at their faculties most surveyed students could define BIM but Mann-Whitney U test $(p=0.01$, Table 1) shows significant difference between Croatia and Slovakia or in other words at the Faculty of Civil Engineering Zagreb more students could define BIM (Košice 90 \%, Zagreb 100 \%, Table 1). Furthermore, Table 1 shows how application of BIM brought progress in education and increased student's understanding of the CM processes (Košice 100 \%, Zagreb $98.21 \%$, Table 1), and consequently allowed progress in education (Košice $83.33 \%$, Zagreb 98.21 \%, Table 1). Likewise, respondents from Košice thought that CAD and Microsoft tools are sufficient ( $73.33 \%$, Table 1$)$ for realistic planning and for complex projects, while the respondents from Zagreb thought completely different $(8.93 \%$, Table 1$)$ whereby Mann-Whitney $U$ test confirms significant difference in their thinking (very low $\mathrm{p}$-value; $\mathrm{p}<0.001$ ). Moreover, most of the students thought that integration of technical specification with costs and time plans (Košice 96.67 \%, Zagreb $96.43 \%$, Table 1), as well as communication between stakeholders who are involved in construction projects, are the areas which are completely missing (Košice $96.67 \%$, Zagreb $100 \%$, Table 1) in today's construction industry. Further, most respondents want to use BIM in their future practice (Košice $80 \%$, Zagreb $100 \%$, Table 1) but the percentage is slightly higher in the Croatia. Accordingly, Mann-Whitney U test shows that there is a significant difference between further students' desire for BIM usage in Croatia and Slovakia ( $p=0.001$, Table 1). Finally, BIM education was reached through single course collaboration and in such environment information exchange between different formats, standards and stakeholders by using IFC standard worked well which the students confirmed with their thinking (Košice $83.33 \%$, Zagreb $76.79 \%$, Table 1). 
Table 1 Comparison of students' answers on specific YES/NO questions

\begin{tabular}{|c|c|c|c|c|c|}
\hline \multirow{2}{*}{ QUESTION } & \multirow{2}{*}{$\begin{array}{l}\text { Mann-Whitney } \\
\text { U test } \\
(\text { alpha }=0.05) \\
\end{array}$} & \multicolumn{2}{|c|}{ KOŠICE } & \multicolumn{2}{|c|}{ ZAGREB } \\
\hline & & YES & NO & YES & NO \\
\hline 1. Can you define Building Information Modeling (BIM)? & $\mathbf{p}=\mathbf{0 . 0 1 7}$ & $90.00 \%$ & $10.00 \%$ & $100.00 \%$ & $0.00 \%$ \\
\hline $\begin{array}{l}\text { 2. In your opinion application of software tools that are } \\
\text { currently available on the market can improve construction } \\
\text { management processes. }\end{array}$ & $\mathrm{p}=0.464$ & $100.00 \%$ & $0.00 \%$ & $98.21 \%$ & $1.79 \%$ \\
\hline $\begin{array}{l}\text { 3. In your opinion application of BIM technology allows } \\
\text { progress in education and understanding of the construction } \\
\text { management discipline. }\end{array}$ & $\mathbf{p}=\mathbf{0 . 0 1 0}$ & $83.33 \%$ & $16.67 \%$ & $98.21 \%$ & $1.79 \%$ \\
\hline $\begin{array}{l}\text { 4. In your opinion CAD and Microsoft tools (Word, Excel, } \\
\text { Microsoft Project) are sufficient for proper and realistic } \\
\text { planning. }\end{array}$ & $\mathbf{p}<\mathbf{0 . 0 0 0 1}$ & $73.33 \%$ & $26.67 \%$ & $8.93 \%$ & $91.07 \%$ \\
\hline $\begin{array}{l}\text { 5. In your opinion construction industry requires the } \\
\text { integration of technical specification with costs and time. }\end{array}$ & $\mathrm{p}=0.955$ & $96.67 \%$ & $3.33 \%$ & $96.43 \%$ & $3.57 \%$ \\
\hline $\begin{array}{l}\text { 6. In your opinion in the construction industry there is a need } \\
\text { for better communication of different professions during the } \\
\text { project design and execution. }\end{array}$ & $\mathrm{p}=0.172$ & $96.67 \%$ & $3.33 \%$ & $100.00 \%$ & $0.00 \%$ \\
\hline 7. Would you like to use BIM in the near future practice? & $\mathbf{p}=\mathbf{0 . 0 0 1}$ & $80.00 \%$ & $20.00 \%$ & $100.00 \%$ & $0.00 \%$ \\
\hline $\begin{array}{l}\text { 8. In your opinion software tools, which are currently } \\
\text { promoted as BIM applications, can mutually exchange } \\
\text { information, different formats, standards (e.g. Vico and } \\
\text { Navisworks or ArchiCAD and Revit). }\end{array}$ & $\mathrm{p}=0.479$ & $83.33 \%$ & $16.67 \%$ & $76.79 \%$ & $23.21 \%$ \\
\hline
\end{tabular}

Therewithal, the results also show that students saw construction companies in their country very inefficient with BIM usage 0-25 \% (Košice $76.67 \%$, Zagreb $100 \%$, Table 2) while they thought that percentage of BIM usage in the world is higher. Most respondents considered that BIM usage in the world is 25-50 \% (Košice $53.33 \%$, Zagreb $67.86 \%$, Table 2) while some of them thought that is slightly higher 50-75 \% (Košice $30 \%$, Zagreb, $26.79 \%$, Table 2). According to Mann-Whitney $U$ test there is a significant difference in a students' thinking about the BIM usage in their own countries ( $p=0.001$, Table 2$)$ but the difference between Croatia and Slovakia is not a significant when talking about the BIM usage in the world ( $\mathrm{p}=0.870$, Table 2$)$.

Besides, results in Table 3 show that the students at the master's level of study at the both universities in general acquired theoretical knowledge connected with the BIM processes (higher percentage of respondents indicated theoretical knowledge for the most BIM competency topics). In addition, Friedman test confirms a given results due to high $\mathrm{p}$-values for Croatia and Slovakia (Košice $\mathrm{p}=0.265$, Zagreb $\mathrm{p}=0.599$, Table 3). Although the acquired knowledge connected with the BIM processes was mostly theoretical, 'Cost Management' (Zagreb $51.79 \%$, Table 3) was included in BIM education as theoretical and practical knowledge while 'Contractual and legal aspects of BIM implementation' (Zagreb $58.93 \%$, Table 3) was missing in the BIM education but only at the Faculty of
Civil Engineering Zagreb. Nevertheless, Mann-Whitney $\mathrm{U}$ test confirms significant differences in the knowledge acquisition related to two discussed BIM competency topics ( $p$-value for 'Contractual and legal aspects of BIM implementation' is 0.029 while for 'Cost Management' is 0.001, Table 3). Although p-value for the BIM knowledge 'Model-progression specification and level-of-detail concepts' ( $p=0.045$, Table 3 ) is lower than alpha (alpha=0.05), previous analysis showed that difference between Košice and Zagreb is not so significant (acquired knowledge at the both faculties was mainly theoretical).

Furthermore, students at the Faculty of Civil Engineering Košice acquired only theoretical knowledge about 'Basic BIM operating skills' (Košice 53.33 \%, Table 4) and 'Laser scanning' (Košice 40 \%, Table 4) while 'Communication tools, media, channels and feedback' (Košice 50 \%, Table 4) and 'Choosing right BIM technologies/ processes/tools for specific purposes' (Košice $56.67 \%$, Table 4) were not included in BIM education. Other BIM competencies connected with BIM technology were included in BIM education, but students' answers are very dispersed (Table 4) so conclusion about level of the BIM knowledge could not me made. On the other hand, students at the Faculty of Civil Engineering Zagreb acquired only theoretical knowledge connected with 'Communication tools, media, channels and feedback' (Zagreb $42.86 \%$, Table 4), 'Ways to store and share 
Table 2 Comparison of students' answers on question: 'In which percentage do you think that BIM technology is applied

\begin{tabular}{|c|c|c|c|c|}
\hline & & $\begin{array}{l}\text { Mann-Whitney U test } \\
\quad(\text { alpha }=0.05)\end{array}$ & KOŠICE & ZAGREB \\
\hline \multirow{4}{*}{$\begin{array}{l}\text { BIM application in Croatia/ } \\
\text { Slovakia }\end{array}$} & $0-25 \%$ & \multirow{4}{*}{$p=0.001$} & $76.67 \%$ & $100.00 \%$ \\
\hline & $25-50 \%$ & & $20.00 \%$ & $0.00 \%$ \\
\hline & $50-75 \%$ & & $3.33 \%$ & $0.00 \%$ \\
\hline & $75-100 \%$ & & $0.00 \%$ & $0.00 \%$ \\
\hline \multirow{4}{*}{ BIM application in the world } & $0-25 \%$ & \multirow{4}{*}{$\mathrm{p}=0.870$} & $13.33 \%$ & $3.57 \%$ \\
\hline & $25-50 \%$ & & $53.33 \%$ & $67.86 \%$ \\
\hline & $50-75 \%$ & & $30.00 \%$ & $26.79 \%$ \\
\hline & $75-100 \%$ & & $3.33 \%$ & $1.79 \%$ \\
\hline
\end{tabular}

Table 3 Students' rate of the competency acquired by learning the following BIM processes throughout their education

\begin{tabular}{|c|c|c|c|c|c|c|c|c|c|}
\hline \multirow{3}{*}{ BIM PROCESSES } & \multirow{3}{*}{$\begin{array}{c}\text { Mann-Whitney } \\
\text { U test } \\
(\text { alpha }=0.05)\end{array}$} & \multicolumn{4}{|c|}{ KOŠICE } & \multicolumn{4}{|c|}{ ZAGREB } \\
\hline & & $\mathbf{T}$ & $\mathbf{P}$ & $\mathbf{T \& P}$ & NO & $\mathbf{T}$ & $\mathbf{P}$ & T\&P & NO \\
\hline & & \multicolumn{4}{|c|}{ Friedman test $($ alpha $=0.05) ; \mathrm{p}=0.265$} & \multicolumn{4}{|c|}{ Friedman test $($ alpha $=0.05) ; \mathrm{p}=0.599$} \\
\hline $\begin{array}{l}\text { Overall construction design } \\
\text { management and contracting } \\
\text { procedures }\end{array}$ & $\mathrm{p}=0.318$ & $60.00 \%$ & $0.00 \%$ & $20.00 \%$ & $20.00 \%$ & $67.86 \%$ & $1.79 \%$ & $21.43 \%$ & $8.93 \%$ \\
\hline $\begin{array}{l}\text { Facility maintenance and } \\
\text { management }\end{array}$ & $\mathrm{p}=0.796$ & $46.67 \%$ & $10.00 \%$ & $10.00 \%$ & $33.33 \%$ & $66.07 \%$ & $0.00 \%$ & $10.71 \%$ & $23.21 \%$ \\
\hline $\begin{array}{l}\text { Advantages and disadvantages } \\
\text { of BIM for design and } \\
\text { construction processes }\end{array}$ & $\mathrm{p}=0.119$ & $40.00 \%$ & $0.00 \%$ & $33.33 \%$ & $26.67 \%$ & $57.14 \%$ & $3.57 \%$ & $35.71 \%$ & $3.57 \%$ \\
\hline $\begin{array}{l}\text { Model-progression } \\
\text { specification and level-of- } \\
\text { detail concepts }\end{array}$ & $p=0.045$ & $46.67 \%$ & $6.67 \%$ & $20.00 \%$ & $26.67 \%$ & $57.14 \%$ & $1.79 \%$ & $3.57 \%$ & $37.50 \%$ \\
\hline $\begin{array}{l}\text { Changes in management } \\
\text { procedures }\end{array}$ & $\mathrm{p}=0.194$ & $63.33 \%$ & $6.67 \%$ & $6.67 \%$ & $23.33 \%$ & $53.57 \%$ & $0.00 \%$ & $8.93 \%$ & $37.50 \%$ \\
\hline Data security & $\mathrm{p}=0.731$ & $36.67 \%$ & $3.33 \%$ & $13.33 \%$ & $46.67 \%$ & $41.07 \%$ & $0.00 \%$ & $10.71 \%$ & $48.21 \%$ \\
\hline Information integrity & $\mathrm{p}=0.689$ & $50.00 \%$ & $3.33 \%$ & $13.33 \%$ & $33.33 \%$ & $50.00 \%$ & $1.79 \%$ & $17.86 \%$ & $30.36 \%$ \\
\hline Design coordination & $\mathrm{p}=0.899$ & $30.00 \%$ & $3.33 \%$ & $30.00 \%$ & $36.67 \%$ & $55.36 \%$ & $1.79 \%$ & $19.64 \%$ & $23.21 \%$ \\
\hline $\begin{array}{l}\text { Constructability review and } \\
\text { analysis }\end{array}$ & $\mathrm{p}=0.923$ & $50.00 \%$ & $0.00 \%$ & $16.67 \%$ & $33.33 \%$ & $33.93 \%$ & $1.79 \%$ & $23.21 \%$ & $41.07 \%$ \\
\hline $\begin{array}{l}\text { Management of information } \\
\text { flows }\end{array}$ & $\mathrm{p}=0.523$ & $46.67 \%$ & $3.33 \%$ & $13.33 \%$ & $36.67 \%$ & $44.64 \%$ & $1.79 \%$ & $10.71 \%$ & $42.86 \%$ \\
\hline $\begin{array}{l}\text { Contractual and legal aspects } \\
\text { of BIM implementation }\end{array}$ & $\mathbf{p}=\mathbf{0 . 0 2 9}$ & $53.33 \%$ & $3.33 \%$ & $6.67 \%$ & $36.67 \%$ & $39.29 \%$ & $1.79 \%$ & $0.00 \%$ & $58.93 \%$ \\
\hline $\begin{array}{l}\text { BIM standardization (in } \\
\text { organizations and projects) }\end{array}$ & $\mathrm{p}=0.467$ & $63.33 \%$ & $0.00 \%$ & $10.00 \%$ & $26.67 \%$ & $67.86 \%$ & $1.79 \%$ & $10.71 \%$ & $19.64 \%$ \\
\hline Cost management & $p=0.001$ & $46.67 \%$ & $3.33 \%$ & $20.00 \%$ & $30.00 \%$ & $37.50 \%$ & $3.57 \%$ & $51.79 \%$ & $7.14 \%$ \\
\hline
\end{tabular}

information (e.g., cloud computing, networking, big-room equipment)' (Zagreb $41.07 \%$, Table 4) and 'Choosing right BIM technologies/ processes/tools for specific purposes' (Zagreb $50 \%$, Table 4) but they acquired theoretical and practical knowledge about 'Basic BIM operating skill' (Zagreb $80.36 \%$, Table 4), 'Modeling with standard catalog elements' (Zagreb $60.71 \%$, Table 4), 'Creating and modeling with custom elements' (Zagreb $50.00 \%$, Table 4)
'Interoperability (file formats, standards, and structure for data sharing)' (Zagreb, $64.29 \%$, Table 4) and 'Cost management' (Zagreb $44.64 \%$, Table 4). BIM competencies 'Massing/solid modeling' (Zagreb $66.07 \%$, Table 4) and 'Laser scanning' (Zagreb $91.07 \%$, Table 4) were missing in the BIM education in Zagreb. Besides, students' answers from Faculty of Civil Engineering Zagreb related to 'Central databases/information repositories' (Table 4) 
Table 4 Students' rate of the competency acquired by learning the following BIM technology throughout their education

\begin{tabular}{|c|c|c|c|c|c|c|c|c|c|}
\hline \multirow{3}{*}{ BIM TECHOLOGY } & \multirow{3}{*}{$\begin{array}{c}\text { Mann- } \\
\text { Whitney U } \\
\text { test } \\
\text { (alpha=0.05) }\end{array}$} & \multicolumn{4}{|c|}{ KOŠICE } & \multicolumn{4}{|c|}{ ZAGREB } \\
\hline & & $\mathbf{T}$ & $\mathbf{P}$ & $\mathbf{T} \& \mathbf{P}$ & NO & $\mathbf{T}$ & $\mathbf{P}$ & T\&P & NO \\
\hline & & \multicolumn{4}{|c|}{ Friedman test $($ alpha $=0.05) ; \mathrm{p}=0.329$} & \multicolumn{4}{|c|}{ Friedman test $(\mathrm{alpha}=0.05) ; \mathrm{p}=0.129$} \\
\hline Basic BIM operating skills & $\mathrm{p}<0.0001$ & $53.33 \%$ & $13.33 \%$ & $13.33 \%$ & $20.00 \%$ & $14.29 \%$ & $1.79 \%$ & $80.36 \%$ & $3.57 \%$ \\
\hline $\begin{array}{l}\text { Modeling with standard } \\
\text { catalog elements }\end{array}$ & $\mathbf{p}=\mathbf{0 . 0 0 3}$ & $20.00 \%$ & $13.33 \%$ & $23.33 \%$ & $43.33 \%$ & $12.50 \%$ & $3.57 \%$ & $60.71 \%$ & $23.21 \%$ \\
\hline $\begin{array}{l}\text { Creating and modeling with } \\
\text { custom elements }\end{array}$ & $\mathrm{p}=0.114$ & $30.00 \%$ & $10.00 \%$ & $23.33 \%$ & $36.67 \%$ & $10.71 \%$ & $5.36 \%$ & $50.00 \%$ & $33.93 \%$ \\
\hline Massing/solid modeling & $\mathrm{p}=0.057$ & $36.67 \%$ & $10.00 \%$ & $13.33 \%$ & $40.00 \%$ & $16.07 \%$ & $3.57 \%$ & $14.29 \%$ & $66.07 \%$ \\
\hline $\begin{array}{l}\text { Central databases/ } \\
\text { information repositories }\end{array}$ & $\mathrm{p}=0.249$ & $36.67 \%$ & $6.67 \%$ & $16.67 \%$ & $40.00 \%$ & $28.57 \%$ & $5.36 \%$ & $32.14 \%$ & $33.93 \%$ \\
\hline $\begin{array}{l}\text { Interoperability (file formats. } \\
\text { standards. and structure for } \\
\text { data sharing) }\end{array}$ & $p=0.0004$ & $20.00 \%$ & $10.00 \%$ & $30.00 \%$ & $40.00 \%$ & $28.57 \%$ & $1.79 \%$ & $64.29 \%$ & $5.36 \%$ \\
\hline $\begin{array}{l}\text { Communication tools. media. } \\
\text { channels and feedback }\end{array}$ & $\mathrm{p}=0.732$ & $16.67 \%$ & $20.00 \%$ & $13.33 \%$ & $50.00 \%$ & $42.86 \%$ & $3.57 \%$ & $16.07 \%$ & $37.50 \%$ \\
\hline $\begin{array}{l}\text { Ways to store and share } \\
\text { information (e.g.. cloud } \\
\text { computing. networking. big- } \\
\text { room equipment) }\end{array}$ & $\mathrm{p}=0.377$ & $26.67 \%$ & $13.33 \%$ & $16.67 \%$ & $43.33 \%$ & $41.07 \%$ & $3.57 \%$ & $25.00 \%$ & $30.36 \%$ \\
\hline $\begin{array}{l}\text { Choosing right BIM } \\
\text { technologies/processes/tools } \\
\text { for specific purposes }\end{array}$ & $\mathbf{p}=\mathbf{0 . 0 3 7}$ & $20.00 \%$ & $10.00 \%$ & $13.33 \%$ & $56.67 \%$ & $50.00 \%$ & $7.14 \%$ & $17.86 \%$ & $25.00 \%$ \\
\hline Laser scanning & $\mathrm{p}<0.0001$ & $40.00 \%$ & $10.00 \%$ & $23.33 \%$ & $26.67 \%$ & $5.36 \%$ & $0.00 \%$ & $3.57 \%$ & $91.07 \%$ \\
\hline Cost management & $p=0.01$ & $33.33 \%$ & $13.33 \%$ & $16.67 \%$ & $36.67 \%$ & $33.93 \%$ & $5.36 \%$ & $44.64 \%$ & $16.07 \%$ \\
\hline
\end{tabular}

are very dispersed so conclusion about level of BIM knowledge could not be made. Therewithal, Mann-Whitney U test shows significant differences in the level of knowledge related to the specific BIM competency topics ( $\mathrm{p}$-value for: 'Basic BIM operating skill' and for 'Laser scanning' is less than 0.0001; 'Interoperability (file formats, standards, and structure for data sharing)' is 0.0004 ; 'Modeling with standard catalog elements' is 0.003 ; 'Choosing right BIM technologies/ processes/tools for specific purposes' is 0.037 ; 'Cost management' is 0.01 , Table 4) between Croatia and Slovakia. Finally, the results of a Friedman test also confirm that students from Slovakia gained some level of the BIM knowledge, but the answers are in general very dispersed (Košice $p=0.329$, Table 4 ) while students from Croatia acquired mostly theoretical or theoretical and practical knowledge (Zagreb $p=0.129$, Table 4) connected with the BIM technology.

Moreover, students at the Faculty of Civil Engineering Košice acquired theoretical knowledge about 'Rapidly generate multiple design alternatives' (Košice $33.33 \%$, Table 5), 'Perform structural analysis' (36.67 \%, Table 5) and 'Rapidly generate and evaluate construction plan alternatives' (Košice 43.33 \%, Table 5) while students at the
Faculty of Civil Engineering Zagreb acquired theoretical knowledge about 'Detect clashes' (Zagreb $35.71 \%$, Table 5) but also theoretical and practical knowledge about 'Create renderings and representations for aesthetic evaluation' (Zagreb $55.36 \%$, Table 5), 'Perform automated quantity takeoff and cost estimation' (Zagreb $73.21 \%$, Table 5), 'Perform automated generation of drawings and documents' (Zagreb $39.29 \%$, Table 5), 'Perform 4D visualization of construction schedules' (Zagreb $58.93 \%$, Table 5) and 'Monitor and visualize process status' (Zagreb $42.86 \%$, Table 5). Other competencies connected with the BIM applications were not included in the BIM education at the any faculty. Thus, high $p$-values (Košice $p=0.384$, Zagreb $\mathrm{p}=0.273$, Table 5) when doing Friedman test verify the fact that most BIM competency topics connected with the BIM applications were not yet included in the BIM education neither in Croatian nor in Slovakia. Further, differences between Faculty of Civil Engineering Košice and Zagreb are also proven by Mann-Whitey U test. BIM competency 'Perform structural analysis' ( $\mathrm{p}$-value is lower than 0.0001 , Table 5) was included in the education in Košice as theoretical knowledge but in Zagreb was missing while BIM competencies 'Create renderings and representations 
Table 5 Students' rate of the competency acquired by learning the following BIM applications throughout their education

\begin{tabular}{|c|c|c|c|c|c|c|c|c|c|}
\hline \multirow{3}{*}{ BIM APPLICATIONS } & \multirow{3}{*}{$\begin{array}{c}\text { Mann- } \\
\text { Whitney U } \\
\text { test } \\
\text { (alpha=0.05) }\end{array}$} & \multicolumn{4}{|c|}{ KOŠICE } & \multicolumn{4}{|c|}{ ZAGREB } \\
\hline & & $\mathbf{T}$ & $\mathbf{P}$ & $\mathbf{T} \& \mathbf{P}$ & NO & $\mathbf{T}$ & $\mathbf{P}$ & T\&P & NO \\
\hline & & \multicolumn{4}{|c|}{ Friedman test $(\mathrm{alpha}=0.05) ; \mathrm{p}=0.384$} & \multicolumn{4}{|c|}{ Friedman test $($ alpha $=0.05) ; p=0.273$} \\
\hline $\begin{array}{l}\text { Create renderings and } \\
\text { representations for aesthetic } \\
\text { evaluation }\end{array}$ & $\mathbf{p}=\mathbf{0 . 0 0 8}$ & $30.00 \%$ & $6.67 \%$ & $16.67 \%$ & $46.67 \%$ & $5.36 \%$ & $5.36 \%$ & $55.36 \%$ & $33.93 \%$ \\
\hline $\begin{array}{l}\text { Rapidly generate multiple design } \\
\text { alternatives }\end{array}$ & $\mathrm{p}=0.471$ & $33.33 \%$ & $13.33 \%$ & $16.67 \%$ & $36.67 \%$ & $23.21 \%$ & $3.57 \%$ & $23.21 \%$ & $50.00 \%$ \\
\hline Perform energy analysis & $\mathbf{p}=\mathbf{0 . 0 0 0 2}$ & $26.67 \%$ & $6.67 \%$ & $10.00 \%$ & $56.67 \%$ & $7.14 \%$ & $0.00 \%$ & $1.79 \%$ & $91.07 \%$ \\
\hline Perform structural analysis & $\mathrm{p}<0.0001$ & $36.67 \%$ & $13.33 \%$ & $13.33 \%$ & $36.67 \%$ & $7.14 \%$ & $0.00 \%$ & $7.14 \%$ & $85.71 \%$ \\
\hline $\begin{array}{l}\text { Perform automated quantity } \\
\text { takeoff and cost estimation }\end{array}$ & $\mathrm{p}<0.0001$ & $33.33 \%$ & $3.33 \%$ & $16.67 \%$ & $46.67 \%$ & $12.50 \%$ & $8.93 \%$ & $73.21 \%$ & $5.36 \%$ \\
\hline Check code compliance & $\mathrm{p}=\mathbf{0 . 0 0 5}$ & $16.67 \%$ & $10.00 \%$ & $6.67 \%$ & $66.67 \%$ & $5.36 \%$ & $0.00 \%$ & $3.57 \%$ & $91.07 \%$ \\
\hline $\begin{array}{l}\text { Evaluate conformance with } \\
\text { program/client values }\end{array}$ & $\mathbf{p}=\mathbf{0 . 0 0 3}$ & $23.33 \%$ & $10.00 \%$ & $10.00 \%$ & $56.67 \%$ & $14.29 \%$ & $1.79 \%$ & $0.00 \%$ & $83.93 \%$ \\
\hline Detect clashes & $\mathrm{p}=0.281$ & $26.67 \%$ & $13.33 \%$ & $3.33 \%$ & $56.67 \%$ & $35.71 \%$ & $5.36 \%$ & $14.29 \%$ & $44.64 \%$ \\
\hline $\begin{array}{l}\text { Perform automated generation of } \\
\text { drawings and documents }\end{array}$ & $\mathrm{p}=0.519$ & $16.67 \%$ & $10.00 \%$ & $30.00 \%$ & $43.33 \%$ & $19.64 \%$ & $3.57 \%$ & $39.29 \%$ & $37.50 \%$ \\
\hline $\begin{array}{l}\text { Perform multiuser editing of a } \\
\text { single-discipline model; multiuser } \\
\text { viewing of merged or separate } \\
\text { multidiscipline models }\end{array}$ & $\mathrm{p}=0.249$ & $23.33 \%$ & $16.67 \%$ & $6.67 \%$ & $53.33 \%$ & $21.43 \%$ & $1.79 \%$ & $10.71 \%$ & $66.07 \%$ \\
\hline $\begin{array}{l}\text { Rapidly generate and evaluate } \\
\text { construction plan alternatives }\end{array}$ & $\mathrm{p}=0.988$ & $43.33 \%$ & $6.67 \%$ & $10.00 \%$ & $40.00 \%$ & $17.86 \%$ & $3.57 \%$ & $26.79 \%$ & $51.79 \%$ \\
\hline $\begin{array}{l}\text { Perform automated generation of } \\
\text { construction tasks }\end{array}$ & $\mathrm{p}=0.280$ & $30.00 \%$ & $3.33 \%$ & $13.33 \%$ & $53.33 \%$ & $21.43 \%$ & $5.36 \%$ & $26.79 \%$ & $46.43 \%$ \\
\hline Perform discrete event simulation & $\mathrm{p}=0.198$ & $30.00 \%$ & $16.67 \%$ & $3.33 \%$ & $50.00 \%$ & $14.29 \%$ & $3.57 \%$ & $33.93 \%$ & $48.21 \%$ \\
\hline $\begin{array}{l}\text { Perform 4D visualization of } \\
\text { construction schedules }\end{array}$ & $\mathbf{p}<0.0001$ & $30.00 \%$ & $10.00 \%$ & $10.00 \%$ & $50.00 \%$ & $19.64 \%$ & $7.14 \%$ & $58.93 \%$ & $14.29 \%$ \\
\hline $\begin{array}{l}\text { Monitor and visualize process } \\
\text { status }\end{array}$ & $p=0.012$ & $36.67 \%$ & $6.67 \%$ & $10.00 \%$ & $46.67 \%$ & $19.64 \%$ & $5.36 \%$ & $42.86 \%$ & $32.14 \%$ \\
\hline $\begin{array}{l}\text { Export data for computer- } \\
\text { controlled fabrication }\end{array}$ & $\mathrm{p}=0.207$ & $20.00 \%$ & $6.67 \%$ & $16.67 \%$ & $56.67 \%$ & $12.50 \%$ & $3.57 \%$ & $35.71 \%$ & $48.21 \%$ \\
\hline $\begin{array}{l}\text { Integrate with project partner } \\
\text { (supply chain) databases }\end{array}$ & $\mathrm{p}=0.584$ & $20.00 \%$ & $10.00 \%$ & $6.67 \%$ & $63.33 \%$ & $23.21 \%$ & $1.79 \%$ & $7.14 \%$ & $67.86 \%$ \\
\hline
\end{tabular}

for aesthetic evaluation' ( $\mathrm{p}=0.008$, Table 5), 'Perform automated quantity takeoff and cost estimation' $(\mathrm{p}<0.0001$, Table 5), 'Perform 4D visualization of construction schedule' ( $p<0.0001$, Table 5) and 'Monitor and visualize process status' ( $p=0.012$, Table 5$)$ were included as theoretical and practical knowledge in Zagreb but in Košice were missing. Besides, Mann-Whitney U test shows significant differences between Croatia and Slovakia when observing BIM competencies 'Perform energy analysis' ( $p=0.0002$, Table 5), 'Check code compliance' $(p=0.005$, Table 5) and 'Evaluate conformance with program/client values' $(p=0.003$, Table 5) but previous analyses showed that listed competencies were not yet included in the BIM education at any of the faculties.

\section{Discussion}

According to previous studies constructability, 4D scheduling, model-based estimating, model-based design, visualization, sustainability, communication, collaboration, clash detection and interoperability represent important knowledge areas for CM BIM education (BecerikGerber, 2011; Bonn and Prigg, 2011; Glick et al., 2010; Poerschke et al., 2010; Ku and Taiebat, 2011). On the one hand, analysis of the results showed that only constructability, model-based estimating and collaboration was acquired through BIM education at the Faculty of Civil Engineering Košice as a theoretical knowledge. On the other hand, at the Faculty of Civil Engineering Zagreb 4D scheduling, model-based estimating, model-based design, 
visualization and interoperability was achieved as theoretical and practical knowledge while constructability, communication, collaboration and clash detection was achieved only as a theoretical knowledge. Besides, sustainability was not yet included in the BIM education at any of the faculties. Thus, students at the Faculty of Civil Engineering Košice and Zagreb after BIM education have had basic BIM skills required for BIM project managers while only students from Zagreb have had skills for BIM mangers/engineers identified by Wang and Laite (2014). Likewise, BIM knowledge acquired by learning BIM processes (Sacks and Pikas, 2013) at the both faculties was generally theoretical. Further, BIM knowledge acquired by learning BIM technology (Sacks and Pikas, 2013) at the Faculty of Civil Engineering Zagreb was theoretical or theoretical and practical while at the Faculty of Civil Engineering Košice level of knowledge was not yet been clear (disperse students' opinion). Finally, knowledge connected with BIM applications (Sacks and Pikas, 2013) was mainly not yet included in the CM educational processes at any of the faculties (some knowledge areas was included in Slovakia like theoretical knowledge while in Croatia like theoretical and practical knowledge). Finally, students have been aware that BIM has been used less in Croatia and Slovakia than in many other countries in EU so BIM awareness was also a part of the BIM education at the both universities.

\section{Conclusion}

In this study we used students' perception and feedback to analyze current BIM education at the Faculty of Civil Engineering Košice and Zagreb but also to confirm importance of including BIM training in educational process of higher student's education. Nevertheless, results showed

\section{References}

Abbas, A., Din, Z. U., Farooqui, R. (2016) "Integration of BIM in construction management education: an overview of Pakistani Engineering universities", Procedia Engineering, 145, pp. 151-157. https://doi.org/10.1016/j.proeng.2016.04.034

Barison, M. B., Santos, E. T. (2010) "BIM teaching strategies: An overview of the current approaches", In: Tizani, W. (ed.) Proceedings of the International Conference on Computing in Civil and Building Engineering, Nottingham University Press, UK, pp. 577-584.

Becerik-Gerber, B., Gerbe, D.J., Ku, K. (2011) "The pace of technological innovation in architecture, engineering, and construction education: Integrating recent trends into the curricula", Journal of Information Technology in Construction, 16, pp. 411-432.

BIM Directive, [online] Available at: https:/en.itec.cat/services/bim/ directive-2014-24-eu/ [Accessed: 30 July 2018] that after BIM education students gained basic BIM knowledge and that students were in general satisfied with acquired BIM skills and BIM tools used in their education.

Moreover, with this study we confirm that BIM education at both faculties should be connected with other departments on the same faculty and other disciplines as well as with real companies and projects. Such extension will provide students wider knowledge related to interoperability, integration, communication, collaboration, standardization and clash detection. Furthermore, BIM education at the Faculty of Civil Engineering Košice should be upgraded with practical BIM training to teach students how to use adequate BIM tools in CM field and to gain BIM skills required for BIM mangers/engineers (not only BIM project managers). Additionally, sustainability was missing in BIM education in Croatia and Slovakia but represent one of the most important knowledge area in today's construction industry. Therefore, sustainability should be included in the BIM education as soon as possible (even as a theoretical knowledge).

Finally, Croatia and Slovakia are countries which do not have long BIM tradition, so their BIM awareness (0-25\%) is very low while BIM education is at its beginnings. Accordingly, further improvement of BIM education will include more practical knowledge, missing BIM knowledge areas, spreading BIM education within undergraduate, graduate and postgraduate study but also connection with practitioners, real companies and projects. These extensions will provide civil engineers with BIM knowledge and skills who, in their near future, will be probably part of Croatian or Slovak construction companies. Thus, BIM education improvement will have good impact on rising BIM awareness and will be good incentive for further BIM implementation in Croatia and Slovakia.

Boon, J., Prigg, C. (2011) "Releasing the potential of BIM in construction education", In: Management and Innovation for a Sustainable Built Environment MISBE, Amsterdam, Netherlands.

Glick, S., Porter, D., Clevenger, C. (2010) "System Component Visualization: The Role of 3D Models in Construction Management Education", In: 46th Annual Associated Schools of Construction International Conference, Boston, USA, pp. 1-8.

Kim, J. L. (2012) "Use of BIM for Effective Visualization Teaching Approach in Construction Education", Journal of Professional Issues in Engineering Education and Practice, 138(3), pp. 214-223. https://doi.org/10.1061/(ASCE)EI.1943-5541.0000102 
Kolarić, S., Mandičak, T., Vukomanović, M., Mesaroš, P. (2017) "Overview of BIM education in the field of Construction Management at the Faculty of Civil Engineering in Košice and the Faculty of Civil Engineering in Zagreb", In: Increasing the efficiency of construction through information modeling of buildings, pp. 34-41.

Kolarić, S., Mandičák, T., Vukomanović, M., Mesároš, P. (2018) "BIM training in construction management educational practices in Croatia and Slovakia", In: Creative Construction Conference, Ljubljana, Slovenia, pp. 1002-1009. https://doi.org/10.3311/CCC2018-130

Kolarić, S., Pavlović, D., Vukomanović, M. (2015) "Application of Building Information Modeling in Education", In: 12th Organization, Technology and Management in Construction Conference, Primošten, Croatia, pp. 384-397.

Kolarić, S., Vukomanović, M., Radujković, M., Pavlović., D. (2016) "Perception of Building Information Modeling within the Croatian Construction Market", In: People, Buildings and Environment Conference, Luhacovice, Czech Republic, pp. 15-25.

Kolarić, S., Vukomanović, M., Stober, D., Dolaček-Alduk, Z. (2017) "Accessing educational approaches to Building Information Modeling (BIM) at construction management master studies in Croatia", Technical gazette, 24(4), pp. 1255-1262. https://doi.org/10.17559/TV-20160922083031

Ku, K., Taiebat, M. (2011) "BIM Experiences and Expectations: The Constructors' Perspective", International Journal of Construction Education and Research, 7(3), pp. 175-197. https://doi.org/10.1080/15578771.2010.544155

Lee, N., Hollar, D. A. (2013) "Probing BIM education in construction engineering and management programs using industry perceptions", In: 49th ASC Annual International Conference, San Luis Obispo, California, USA, pp. 467-476.

Macdonald, J. A. (2012) "A framework for collaborative BIM education across the AEC disciplines", In: 37th Annual Conference of Australasian University Building Educators Association (AUBEA), Sydney, Australia, 2012, pp. 223-230.

Malleson, A., Kato, H., Popíšilová, B., Watson., D., Friborg, G. (2016) "NBS International BIM Report 2016", NBS, United Kingdom.

Mesároš, P., Mandičák, T. (2017) "Exploitation and Benefits of BIM in Construction Project Management", In: IOP Conference Series: Materials Science and Engineering, Prague, Czech Republic, pp. $1-7$. https://doi.org/10.1088/1757-899X/245/6/062056

Mesároš, P., Mandičák, T., Mesárošová, A., Behún, M. (2016) "Developing managerial and digital competencies trough BIM technologies in construction industry", In: International Conference on Emerging eLearning Technologies and Applications (ICETA), Vysoke Tatry, Slovakia, pp. 217-222.

https://doi.org/10.1109/ICETA.2016.7802095
Pikas, E, Sacks, R., Hazzan, O. (2013) "Building Information Modeling Education for Construction Engineering and Management. II: Procedures and Implementation Case Study", Journal of Construction Engineering and Management, 139(11), pp. 05013002 . https://doi.org/10.1061/(ASCE)CO.1943-7862.0000765

Poerschke, U., Holland, R.J., Messner, J.I., Pihlak, M. (2010) "BIM collaboration across six disciplines", In: Conference on Computing in Civil and Building Engineering, Nottingham, UK, pp. 575-671.

Puolitaival, T., Boot, T., Ghaffarian Hoseini, A., Park, K.S. (2017) "BIM education: case New Zealand", In: Australasian Universities Building Education Association Conference, Auckland, New Zealand, pp. 210-218. https://oi.org/10.29007/lcf3

Puolitaival, T., Perry, F. (2016) "Practical challenges of BIM education", Structural Survey, 34(45), pp. 351-366. https://doi.org/10.1108/SS-12-2015-0053

Sacks, R., Pikas, E. (2013) "Building Information Modeling Education for Construction Engineering and Management. I: Industry Requirements, State of the Art, and Gap Analysis", Journal of Construction Engineering and Management, 139(11), pp. 04013016. https://doi.org/10.1061/(ASCE)CO.1943-7862.0000759

Salleh, H., Phui Fung, W. (2014) "Building Information Modeling application: focus-group discussion", Građevinar, 8(66), pp. 705-714. https://doi.org/10.14256/JCE.1007.2014

Shelbourn, M., Macdonald, J., McCuen, T., Lee, S. (2017) "Students' perceptions of BIM education in the higher education sector: A UK and US perspective", Industry and Higher Education, 31(5), pp. 293-304. https://doi.org/10.1177/0950422217725962

Suwal, S. Singh, V. (2018) "Assessing students' sentiments towards the use of a Building Information Modelling (BIM) learning platform in a construction project management course", European Journal of Engineering Education, 43(4), pp. 492-506. https://doi.org/10.1080/03043797.2017.1287667

Uhm, M., Lee, G., Jeon, B. (2017) "An analysis of BIM jobs and competencies based on the use of terms in the industry", Automation in Construction, 81, pp. 67-98. https://doi.org/10.1016/j.autcon.2017.06.002

Wang, L., Leite, F. (2014) "Process-Oriented Approach of Teaching Building Information Modeling in Construction Management", Journal of Professional Issues in Engineering Education and Practice, 140(4), pp. 04014004.

https://doi.org/10.1061/(ASCE)EI.1943-5541.0000203

Yusuf, B. Y., Ali, K. N., Embi, M. R. (2016) "Building Information Modeling as a Process of Systemic Changes for Collaborative Education in Higher Institution", Procedia - Social and Behavioral Sciences, 219, pp. 820-827.

https://doi.org/10.1016/j.sbspro.2016.05.072 